\title{
Credit Risk Management and Performance of Deposit Money Banks in Nigeria
}

\author{
Harcourt, Edwin E \\ Department of Finance \& Banking, University of Port Harcourt, Port Harcourt, Nigeria
}

\begin{abstract}
This paper investigates the impact of credit risk management on the performance of deposit money banks in Nigeria using the overparameterised and parsimonious ECM and Granger causality. Data for the study were sourced from the CBN Statistical Bulletin, stock exchange fact book and World Development Indicators (WDI) for the period 1989 to 2014. Our findings demonstrate that the selected credit risk management indicators under study significantly impact on the performance of deposit money banks measured as return on assets (ROA) and return on equity (ROE). The findings also showed evidence of significant granger causality relationship between the various credit risk management indicators and the various measures of performance. There is a uni-directional granger causality relationship from LDR to ROA and from NLTL to $R O E$ respectively. Based on the findings of the study, it is therefore recommended that deposit money banks should be cautious in setting credit policies so as not to negatively affect their operations, and ensure judicious utilization of deposits and maximization of profits in both the short and long term.
\end{abstract}

Keyword: Credit risk management, performance, deposit money banks

\section{INTRODUCTION}

The global financial meltdown of 2008 accelerated a fundamental change in the banking industry the world over. It led to the diversification of banking services in order to become more competitive and also allowed for mergers and acquisitions in the industry. The impact of the meltdown was so much that almost all sectors of global business was affected; with the banking sector most affected. Because of the intermediation functions of deposit money banks, which include credit creation, they are exposed to a lot of risks including default and credit risks. These risks if not properly handled most times lead to financial distress and ultimately bankruptcy. Deposit money banks generate credit to their customers with the major objective of making profit in the process. The non-payment of loans or other forms of credit by debtors plays an important role in banks profitability because a large part of banks revenue is interest generated from loans.

The rise in non-performing loans contributed significantly to bank failures and financial distress in the banking sector. Credit risk management played a major role during the crisis and has received significant attention in the eyes of the public and regulators. This has given cause to stakeholders and regulators in the Nigerian banking industry to consider not just the profits made during the cause of operation but also critically examine frameworks used to manage risks associated with credit facilities in the sector so as to safeguard shareholders' interests. The reforms in the banking sector proceeded against the backdrop of banking crisis due to the undercapitalization of deposit money banks; weak management practices; and bad corporate governance practices of banks (Uchendu, 2005). The reforms and recapitalization was intended to stop perceived or impending banking sector crises so as to prevent subsequent failures.

The focus on risk has intensified and organizations are beginning to enhance the management of key risks, which include: credit risk as a priority, operational risk, liquidity risk, market risk, reputational risk. The motivation for this study is credit risk. Increasing shareholder's return is a significant objective of shareholders.

Available records showed that between 1999 and 2009, the volume of bad loans rose up to 35 percent of total loans granted. Several factors have been attributed to this increase. They include amongst others lack of adequate collaterals, poor credit processing and undue interference by senior management staff and board members. This has impacted negatively on the performance of deposit 
money banks. Deposit money banks in Nigeria were faced with a major crisis which were traced to the high figures of non-performing loans according to the Central Bank of Nigeria (CBN).

The purpose of this paper is to ascertain whether there is any significant relationship between credit risk management and the performance of deposit money banks in Nigeria. The following null hypotheses were formulated to enable us achieve the stated objectives of the paper:

Credit risk management does not have any significant impact on the return on assets of deposit money banks in Nigeria.

Credit risk management does not have any significant impact on the return on equity of deposit money banks in Nigeria.

\section{Literature REVIEW}

\subsection{Theoretical Framework}

\subsubsection{Loan Pricing Theory}

Banks cannot always set high interest rates. Banks should consider the problems of adverse selection and moral hazard since it is very difficult to forecast the borrower type at the start of the banking relationship. If banks set interest rates too high, they may induce adverse selection problems because high-risk borrowers are willing to accept these high rates. Once these borrowers receive the loans, they may develop moral hazard behaviour or so called borrower moral hazard since they are likely to take on highly risky projects or investments. From this reasoning, it is usual that in some cases we may not find that the interest rate set by banks is commensurate with the risk of the borrowers.

\subsubsection{Firm Characteristics Theory}

These theories predict that the number of borrowing relationships will be decreasing for small, high quality, opaque in terms of information and constraint firms, all other things been equal. Robert and Gary (1994) state that the most obvious characteristics of failed banks is not poor operating efficiency, however, but an increased volume of non-performing loans. Non-performing loans in failed banks have typically been associated with regional macroeconomic problems. DeYoung and Whalen (1994) observed that the US Office of the Comptroller of the Currency found the difference between the failed banks and those that remained healthy or recovered from problems was the caliber of management. Superior mangers not only run their banks in a cost efficient fashion, and thus generate large profits relative to their peers, but also impose better loan underwriting and monitoring standards than their peers which result to better credit quality, Kargi (2011).

\subsubsection{Theory of Multiple-Lending}

It is found in literature that banks should be less inclined to share lending (loan syndication) in the presence of well developed equity markets. Both outside equity and mergers and acquisitions increase banks"e lending capacities, thus reducing their need of greater diversification and monitoring through share lending. This theory has a great implication for banks in Nigeria in the light of the recent 2005 consolidation exercise in the industry.

\subsubsection{The Signaling Arguments}

The signaling argument states that good companies should provide more collateral so that they can signal to the banks that they are less risky type borrowers and then they are charged lower interest rates. Meanwhile, the reverse signaling argument states that banks only require collateral and or covenants for relatively risky firms that also pay higher interest rates.

\subsubsection{Credit Market Theory}

A model of the neoclassical credit market postulates that the terms of credits clear the market. If collateral and other restrictions (covenants) remain constant, the interest rate is the only price mechanism. With an increasing demand for credit and a given customer supply, the interest rate rises, and vice versa. It is thus believed that the higher the failure risks of the borrower, the higher the interest premium.

The theoretical framework for this study factors the degree of openness of an economy in the analysis of the influence of both internal and external factors on interest rate movements in a semi-open 
economy like Nigeria. Suppose we have a closed economy, in which there is no inflow or outflow of capital and the demand for money is the demand for real money. In such an economy, money is held by the economic units purely to finance transactions and increase the demand for money with real output. However, it is worthy of note, that holding money has an opportunity cost that is measured by the nominal rate of interest, with higher interest rates discouraging the holding of wealth in the form of money. If $\mathrm{M}$ is assumed to be the nominal stock of money and $\mathrm{P}$ is the price level, real money demand is defined as $\mathrm{M} / \mathrm{P}$, which is a function of the interest rate, $\mathrm{i}$ and the output, Y. Short run equilibrium in the money market exists, when the demand for money is equal to the supply of money.

\subsection{Credit Risk Management Strategies}

The credit risk management strategies are measures employed by banks to avoid or minimize the adverse effect of credit risk. A sound credit risk management framework is crucial for banks so as to enhance profitability guarantee survival. According to Lindgren (1987), the key principles in credit risk management process are sequenced as follows; establishment of a clear structure, allocation of responsibility, processes have to be prioritized and disciplined, responsibilities should be clearly communicated and accountability assigned. The strategies for hedging credit risk include but not limited to these;

i. Credit Derivatives: This provides banks with an approach which does not require them to adjust their loan portfolio. Credit derivatives provide banks with a new source of fee income and offer banks the opportunity to reduce their regulatory capital. The commonest type of credit derivative is credit default swap whereby a seller agrees to shift the credit risk of a loan to the protection buyer. Frank Partnoy and David Skeel in Financial Times of 17 July, 2006 said that "credit derivatives encourage banks to lend more than they would, at lower rates, to riskier borrowers". Recent innovations in credit derivatives markets have improved lenders" abilities to transfer credit risk to other institutions while maintaining relationship with borrowers.

ii. Credit Securitization: It is the transfer of credit risk to a factor or insurance firm and this relieves the bank from monitoring the borrower and fear of the hazardous effect of classified assets. This approach insures the lending activity of banks. The growing popularity of credit risk securitization can be put down to the fact that banks typically use the instrument of securitization to diversify concentrated credit risk exposures and to explore an alternative source of funding by realizing regulatory arbitrage and liquidity improvements when selling securitization transactions. A cash collateralized loan obligation is a form of securitization in which assets (bank loans) are removed from a bank's balance sheet and packaged (tranched) into marketable securities that are sold on to investors via a special purpose vehicle (SPV).

iii. Compliance to Basel Accord: The Basel Accord is an international principles and regulations guiding the operations of banks to ensure soundness and stability. The Accord was introduced in 1988 in Switzerland. Compliance with the Accord means being able to identify, generate, track and report on risk-related data in an integrated manner, with full audit ability and transparency and creates the opportunity to improve the risk management processes of banks. The New Basel Capital Accord places explicitly the onus on banks to adopt sound internal credit risk management practices to assess their capital adequacy requirements (Chen and Pan, 2012).

iv. Adoption of a sound internal lending policy: The lending policy guides banks in disbursing loans to customers. Strict adherence to the lending policy is by far the cheapest and easiest method of credit risk management. The lending policy should be in line with the overall bank strategy and the factors considered in designing a lending policy should include; the existing credit policy, industry norms, general economic conditions of the country and the prevailing economic climate (Kithinji, 2010).

v. Credit Bureau: This is an institution which compiles information and sells this information to banks as regards the lending profile of a borrower. The bureau awards credit score called statistical odd to the borrower which makes it easy for banks to make instantaneous lending decision. Example of a credit bureau is the Credit Risk Management System (CRMS) of the Central Bank of Nigeria $(\mathrm{CBN})$.

vi. Policy Strategy: Banks and other financial institutions should endeavour to have a credit policy manual which should be updated regularly to meet the changing business environment. Such credit 
manuals should provide rules and regulations guiding the important aspect of work being performed within their credit department. The reason for the manual is to understand and recognize important issues and to ensure consistent thinking and action on these issues by people inside the department. One of the fundamental things to remember is that the work being done by the credit department affects many people and departments within the organization.

Graham suggested that the credit policy manual should be detailed and provides guidelines in terms of the following: documentations required; department of credit analysis and format to be used; statutory requirements; approval process; credit procedure; Communication channels between headquarter, the branches and customers; Penalties for defaulters, etc.

\subsection{Non- Performing Loans and Deposit Money Banks in Nigeria}

Central Bank of Nigeria (2010), under the Prudential Guidelines, non-performing credit facilities were subject to classification into three categories, namely; sub-standard, doubtful or lost on the bases of certain criteria below:

(1) Sub-Standard: The following objective and subjective criteria could be used to identify substandard loan:

- Objective criteria: facilities on which unpaid principal and/or interest remain outstanding for more than 90 days but less than 180 days.

- Subjective criteria: facilities which display well defined weaknesses which could affect the ability of borrowers to repay, such as inadequate cash flow to service debt, under capitalization or insufficient working capital, absence of adequate financial information or collateral documentation, irregular payment of principal and/or interest, and inactive accounts where withdrawals exceed repayments can barely cover interest charges.

(2) Doubtful: The following objective and subjective criteria should also be used to identify doubtful credit facilities:

- Objective criteria: facilities on which unpaid principal and/or interest remain outstanding for at least 180 days but less than 360 days and are not secured by legal title to leased assets or perfected realizable collateral in the process of collection or realization.

- Subjective criteria: facilities which in addition to the weakness associated with sub standard credit facilities reflect that full repayment of the debt is not certain or that realizable collateral values will be insufficient to cover bank's exposure.

(3) Lost Credit Facilities: The following objective and subjective criteria should be used to identify lost credit facilities:

- Objective criteria: facilities on which unpaid principal and/or interest remain outstanding for 360 days or more and are not secured by legal title to leased assets or perfected realizable collater al in the course of collection or realization.

- Subjective criteria: facilities which in addition to the weakness associated with doubtfulcredit are considered uncollectable and are of such little value that continuation as a bankable asset is unrealistic such as facilities that have been abandoned, facilities secured with unmarketable and unrealizable securities and facilities extended to judgement debtors with no means or fore closable collateral to settle debts.

\subsection{Empirical Evidence}

There are several forces operating in the banking sector that act in certain ways affecting the business activity of lending. These forces may inevitably expose banks to a very high credit risk which may lead to distress including bankruptcy. Prominent among these forces are risk, interest rates, taxation, inflation, etc. Risk is seen as a variation that exists in returns when the expected fails to be actualized. It is easy to see that risk affects the lending function of banks since the activity itself is filled with risk. Such risks that may arise in lending include; interest rate risk, liquidity risk and default risk. Credit risk is defined as the potential that a bank borrower or counterparty will fail to meet its obligation in accordance with agreed terms. The goal of credit risk management is to maximize the bank's risk adjusted rate of return by maintaining credit risk exposure within acceptable parameters, (BCSB 2001). 
Kargi (2011) sees credit creation as a major source of income to the banks and therefore postulates that credit risk management must be seen as critical for the survival banks. According to Sanusi (2002) despite the fact that most deposit money banks have risk management departments, statistics showed that between 1999 and 2009 the volume of bad loans was as high as 35\% of total credits granted. This high volume of bad loan was attributed to very poor credit appraisal process which has impacted negatively on the performance of banks.

Ahmad and Ariff, (2007) conducted a comparative study of some key determinants of credit risks associated with commercial banks in developing and developed economies. They opined that it is important for banking systems that offer multi-products and services to be properly regulated. Banks must maintain proper liquidity in order to be able to carry on their basic function of intermediation.

(Kithinji, 2010) analyzed the effect of credit risk management on the profit of banks from 2004 to 2008. His variables included volume of credits granted, volume of non-performing loans and profits of banks for the period. His findings showed that neither the volume of credit nor non-performing impacted on banks profit for the period under review.

(Owojori et al, 2011) used records obtained from liquidated banks; they concluded that the inability of bank management to recover loans and advances extended to customers such as relations, directors, etc were the contributing to the bank distress in 1995. Records showed that 60 out of the 115 banks that were distressed had non-performing loans of $67 \%$ of their total loans. It worsened and to $79 \%$ in 1996, 82\% in 1997 and by December 2002, 35 of the distressed banks licenses were revoked by the Central Bank of Nigeria $(\mathrm{CBN})$.

The Basel Committee on Banking Supervision (1999) asserts that loans are the largest and most obvious source of credit risk, while others are found on the various activities that the bank involved itself with. Therefore, it is a requirement for every bank worldwide to be aware of the need to identify measure, monitor and control credit risk while also determining how credit risks could be lowered. This means that a bank should hold adequate capital against these risks and that they are adequately compensated for risks incurred. This is stipulated in Basel II, which regulates banks about how much capital they need to put aside to guide against these types of financial and operational risks they face, Kargi (2011).

In a collaborative study by the CBN and the Nigeria Deposit Insurance Corporation \{NDIC \} in 1995, operators of financial institutions confirmed that bad loans and advances contributed most to the distress. In their assessment of factors responsible for the distress, the operators ranked bad loans and advances first, with a contribution of $19.5 \%$.

In 1990, the CBN issued the circular on capital adequacy which relate bank's capital requirements to risk weighted assets. It directed the banks to maintain a minimum of 7.25 percent of risk-weighted assets as capital; to hold at least 50 percent of total components of capital and reserves; and to maintain the ratio of capital to total risk weighted assets as a minimum of 8 percent from January, 1992. Despite these measure and reforms embodied in such legal documents as CBN Act No. 24 of 1991 and Banks and other financial institutions (BOFI) Act No.25 of 1991 as amended, the number of technically insolvent banks increased significantly during the 1990 s

Furthermore, Felix and Claudine (2008) investigated the relationship between bank performance and credit risk management focusing on emerging economies. It could be inferred from their findings that return on equity (ROE) and return on assets (ROA) both measuring profitability were inversely related to the ratio of non-performing loans to total loans and advances of financial institutions thereby leading to a decline in profitability.

Ahmed, Takeda and Shawn (1998) in their study found that loan loss provision has a significant positive influence on non-performing loans. For the authors therefore, an increase in loan loss provision indicates an increase in credit risk and deterioration in the quality of loans consequently affecting bank performance adversely.

\section{Methodology}

The research method applied in this study is quantitative. Besides, both historical and descriptive research design adopted. The study investigates the relationship between the dependent variable 
(performance) and the independent variables (credit risk) from 1989 to 2014. Annual time series data obtained from CBN statistical bulletin, Stock Exchange fact book and the World Development Indicators (WDI) shall be used.

\subsection{Description of Variables}

\subsubsection{Dependent Variable}

In this study, performance is the dependent variable represented by return on assets (ROA), defined as profit after tax divided by total assets and return on equity (ROE), defined as profit after tax divided by equity. The above performance indicators have been used extensively in previous studies and with satisfactory results (Aziz, Ibrahim and Isa, 2009). We have therefore chosen to use return on equity $(\mathrm{ROE})$ and return on assets (ROA) as measures of performance representing the dependent variable.

\subsubsection{Independent Variables}

Credit risk is the risk of counter-party failure in meeting the payment obligation on the specific date. Credit risk management is an important challenge to deposit money banks in Nigeria and failure on this front leads to failure of banks. In modelling the influence of credit risk, the ratios of total loan to deposit (LDR), non-performing loans to total loans (NLTL) and total loans to total assets (TLTA) are used.

\subsection{Model specification}

The empirical models to be estimated in this study are specified functionally as:

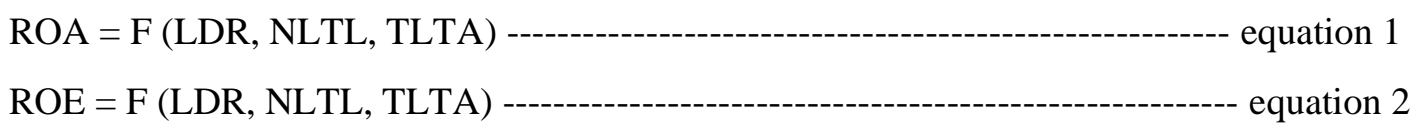

Econometrically, the regression models are transformed as:

ROAt $=\beta_{o}+\beta_{1} L D R t+\beta_{2}$ NLTLt $+\beta_{3}$ TLTAt + Ut -------------------------- equation 3

$\mathrm{ROEt}=\beta_{\mathrm{o}}+\beta_{1} \mathrm{LDRt}+\beta_{2} \mathrm{NLTLt}+\beta_{3}$ TLTAt $+\mathrm{Ut}$--------- equation 4

Where:

ROA $=$ Return on Assets

$\mathrm{ROE}=$ Return on Equity

LDR $=$ Total loans and advances-to-total deposit ratio

NLTL $=$ Non-performing loans-to-total loans ratio

TLTA $=$ Total loans and advances-to-total assets ratio

$\mathrm{t}=$ Time series data

$\beta_{0}=$ Intercept

$\beta_{1}, \beta_{2}, \beta_{3}=$ Parameters of the coefficients

$\mathrm{U}=$ Error or disturbance Term

$\beta_{1}, \beta_{2},<0 ; \beta_{3}>0$

\section{Analyses of Data}

Various descriptive statistics are calculated from the variables under study in order to describe the basic characteristics of these variables. As can be seen from table 4.1, all the variables are asymmetrical. More precisely, skewness is positive for all the variables except the ratios of total loans and advances to deposit and total loans and advances to total assets. Kurtosis value of all the variables also shows data is not normally distributed as the values of kurtosis are deviated from 3 . The Jarque Bera statistics and p-values accept the normality assumption at 5\% level of significance for all the variables. 
Credit Risk Management and the Performance of Deposit Money Banks in Nigeria

Table1. Descriptive Statistics

\begin{tabular}{|c|c|c|c|c|c|}
\hline & ROA & ROE & LDR & NLTL & TLTA \\
\hline Mean & 529.6319 & 402.7062 & 63.88115 & 23.51962 & 0.382077 \\
\hline Median & 543.2500 & 401.4250 & 64.93000 & 21.50000 & 0.380000 \\
\hline Maximum & 684.5600 & 478.2200 & 85.66000 & 45.40000 & 0.530000 \\
\hline Minimum & 410.0200 & 326.2900 & 36.25000 & 3.000000 & 0.210000 \\
\hline Std. Dev. & 69.06888 & 36.57816 & 12.81796 & 13.98437 & 0.079570 \\
\hline Skewness & 0.087669 & 0.173143 & -0.475953 & 0.045553 & -0.137823 \\
\hline Kurtosis & 2.663357 & 2.825027 & 2.497870 & 1.775412 & 2.488850 \\
\hline Jarque-Bera & 0.156078 & 0.163073 & 1.254782 & 1.633575 & 0.365359 \\
\hline Probability & 0.924928 & 0.921699 & 0.533983 & 0.441849 & 0.833035 \\
\hline Sum & 13770.43 & 10470.36 & 1660.910 & 611.5100 & 9.934000 \\
\hline Sum Sq. Dev. & 119262.7 & 33449.05 & 4107.505 & 4889.066 & 0.158284 \\
\hline Observations & 26 & 26 & 26 & 26 & 26 \\
\hline
\end{tabular}

Source: Author's compilation from Eviews

Table2. Correlation matrix

\begin{tabular}{|c|c|c|c|c|c|}
\hline & ROA & ROE & LDR & NLTL & TLTA \\
\hline ROA & 1 & & & & \\
\hline ROE & 0.7557 & 1 & & & \\
\hline LDR & -0.3257 & -0.3332 & 1 & & \\
\hline NLTL & -0.6555 & -0.6073 & 0.2147 & 1 & 1 \\
\hline TLTA & 0.3144 & 0.4461 & 0.3233 & -0.6295 & \\
\hline
\end{tabular}

Source: Author's compilations from Eviews

Table2 above shows that the variables are among themselves both positively and negatively correlated.

Table3. Unit root result

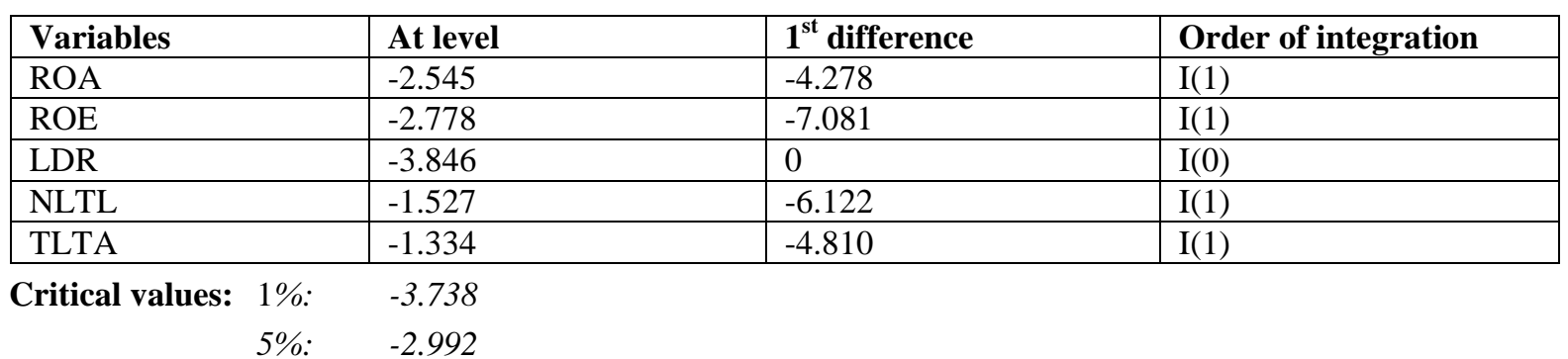

Source: Author's compilations from Eviews

Table 3 above presents the summary results of the ADF unit root tests. All the variables are tested at levels and first difference for stationarity using the ADF test. The result shows that all the variables are stationary at first difference except the ratio of total loans and advances to total deposit which is stationary at level. This indicates that the regression is no more spurious but real. That is to say, all the variables are individually stationary and stable.

Table4. Johansen cointegration test results

\begin{tabular}{|l|l|l|l|l|l|}
\hline \multirow{2}{*}{ Model } & \multicolumn{2}{|c|}{ Variables } & \multicolumn{3}{c|}{ No. of Co-integrating equation @ 5\% } \\
\cline { 2 - 6 } & Dependent Variables & Independent Variables & Trace test & $\begin{array}{l}\text { Maximum- } \\
\text { eigenvalue }\end{array}$ & Lag Intervals \\
\hline 1 & ROA & LDR, NLTL, TLTA & 2 & 2 & 1 to 2 \\
\hline 2 & ROE & LDR, NLTL, TLTA & 2 & 2 & 1 to 2 \\
\hline
\end{tabular}

Source: Authors compilations from Eviews

Table 4 shows the summary results of the Johansen Co-integration test employed to test for the long run co-integration relationship between bank performance represented by return on assets (ROA) and return on equity (ROE); and asset quality management of deposit money banks represented by the ratios of total loans and advances to total deposit, total non-performing loans to total loans and advances and total loans and advances to total assets. There are two co-integrating equations each for both the trace tests and the maximum-eigenvalue test with one to two lag intervals taken at 5 percent significant level 
Table5. Parsimonious ECM result with ROA as the dependent variable

\begin{tabular}{|c|c|c|c|c|}
\hline \multicolumn{3}{|l|}{ Dependent Variable: D(ROA) } & & \\
\hline \multicolumn{5}{|l|}{ Method: Least Squares } \\
\hline \multicolumn{5}{|l|}{ Date: $08 / 27 / 16$ Time: $16: 57$} \\
\hline \multicolumn{5}{|l|}{ Sample (adjusted): 19922014} \\
\hline \multicolumn{5}{|c|}{ Included observations: 23 after adjustments } \\
\hline Variable & Coefficient & Std. Error & t-Statistic & Prob. \\
\hline $\mathrm{C}$ & -3.079485 & 8.004890 & -0.384700 & 0.7055 \\
\hline $\mathrm{D}(\mathrm{LDR})$ & 1.054446 & 0.688977 & 1.530451 & 0.1454 \\
\hline $\mathrm{D}(\mathrm{NLTL})$ & -3.191229 & 0.948006 & -3.366255 & 0.0039 \\
\hline D(NLTL(-1)) & -2.090412 & 0.911430 & -2.293552 & 0.0357 \\
\hline $\mathrm{D}(\mathrm{TLTA}(-2))$ & 316.6873 & 181.5407 & 1.744442 & 0.1003 \\
\hline $\mathrm{D}(\mathrm{ROA}(-1))$ & 0.246834 & 0.194719 & 1.267643 & 0.2231 \\
\hline ECM1(-1) & -0.599575 & 0.188684 & -3.177662 & 0.0058 \\
\hline R-squared & 0.595606 & \multicolumn{2}{|l|}{ Mean dependent var } & 9.671739 \\
\hline Adjusted R-squared & 0.443958 & \multicolumn{2}{|l|}{ S.D. dependent var } & 47.14857 \\
\hline S.E. of regression & 35.15786 & \multicolumn{2}{|l|}{ Akaike info criterion } & 10.20336 \\
\hline Sum squared resid & 19777.20 & \multicolumn{2}{|l|}{ Schwarz criterion } & 10.54895 \\
\hline Log likelihood & -110.3387 & \multicolumn{2}{|l|}{ Hannan-Quinn criter. } & 10.29028 \\
\hline F-statistic & 3.927558 & \multicolumn{2}{|l|}{ Durbin-Watson stat } & 1.328450 \\
\hline Prob(F-statistic) & 0.013257 & & & \\
\hline
\end{tabular}

Source: Author's compilations from Eviews

Table 5 shows that R-squared is 0.60 while adjusted R-squared is 0.44 indicating that about $44 \%$ total changes in ROA is caused by the combined effect of the independent variables. On the other hand, the remaining 56\% is caused largely by factors exogenous to the model which is accounted for by the error term. The result also shows that the entire model is significant at $5 \%$ confidence interval. The coefficient of the ECM1(-1) shows the expected negative sign and is significant at $5 \%$ level. The speed of adjustment to equilibrium is about $60 \%$ every year.

Also from the parsimonious result, all the independent variables conform to the apriori expectation except the ratio of total loans and advances to total deposit (LDR) which is positively signed against the ROA but insignificant. The ratio of non-performing loans to total loans and advances (NLTL) is negatively signed and significant at $5 \%$ confidence interval. While the ratio of total loans and advances to total assets (TLTA) as expected is positively signed but insignificant at $5 \%$ significant level.

Table6. Parsimonious ECM result with ROE as the dependent variable

\begin{tabular}{|c|c|c|c|c|}
\hline \multicolumn{5}{|c|}{ Dependent Variable: D(ROE) } \\
\hline \multicolumn{5}{|c|}{ Method: Least Squares } \\
\hline \multicolumn{5}{|c|}{ Date: $08 / 27 / 16$ Time: $16: 44$} \\
\hline \multicolumn{5}{|c|}{ Sample (adjusted): 19922014} \\
\hline \multicolumn{5}{|c|}{ Included observations: 23 after adjustments } \\
\hline Variable & Coefficient & Std. Error & t-Statistic & Prob. \\
\hline $\mathrm{C}$ & 6.591684 & 5.506453 & 1.197084 & 0.2499 \\
\hline D(TLTA) & 315.9583 & 171.5101 & 1.842214 & 0.0853 \\
\hline $\mathrm{D}(\mathrm{TLTA}(-1))$ & -206.2842 & 116.3681 & -1.772687 & 0.0966 \\
\hline $\mathrm{D}(\mathrm{TLTA}(-2))$ & -160.3000 & 191.7488 & -0.835989 & 0.4163 \\
\hline $\mathrm{D}(\mathrm{LDR})$ & -0.802685 & 0.673837 & -1.191216 & 0.2521 \\
\hline $\mathrm{D}(\mathrm{LDR}(-2))$ & 1.345358 & 0.797931 & 1.686057 & 0.1125 \\
\hline $\mathrm{D}(\mathrm{NLTL}(-2))$ & -0.459264 & 0.564697 & -0.813292 & 0.4288 \\
\hline $\mathrm{ECM}(-1)$ & -0.883077 & 0.234967 & -3.758305 & 0.0019 \\
\hline R-squared & 0.710406 & \multicolumn{2}{|c|}{ Mean dependent var } & 5.001304 \\
\hline Adjusted R-squared & 0.575263 & \multicolumn{2}{|c|}{ S.D. dependent var } & 35.05688 \\
\hline S.E. of regression & 22.84723 & \multicolumn{2}{|c|}{ Akaike info criterion } & 9.363745 \\
\hline Sum squared resid & 7829.939 & \multicolumn{2}{|c|}{ Schwarz criterion } & 9.758700 \\
\hline Log likelihood & -99.68307 & \multicolumn{2}{|c|}{ Hannan-Quinn criter. } & 9.463075 \\
\hline F-statistic & 5.256671 & \multicolumn{2}{|c|}{ Durbin-Watson stat } & 1.572307 \\
\hline Prob(F-statistic) & 0.003431 & & & \\
\hline
\end{tabular}

Source: Author's compilations from Eviews 
Table 6 shows that R-squared is 0.71 while adjusted R-squared is 0.58 indicating that about $58 \%$ total changes in ROE is caused by the combined effect of the independent variables. On the other hand, the remaining $42 \%$ is caused largely by factors exogenous to the model which is accounted for by the error term. The result also shows that the entire model is significant at 5\% confidence interval. The coefficient of the ECM (-1) shows the expected negative sign and is significant at 5\% level. The speed of adjustment to equilibrium is about $88 \%$ every year.

Also from the parsimonious result, all the independent variables conform to the apriori expectation except the ratio of total loans and advances to total deposit (LDR) which is also positively signed against the ROE but insignificant. The ratio of non-performing loans to total loans and advances (NLTL) is negatively signed but insignificant at 5\% confidence interval. While the ratio of total loans and advances to total assets (TLTA) as expected is positively signed but insignificant at 5\% significant level.

Table7. Pairwise Granger causality test result

\begin{tabular}{|c|c|c|c|}
\hline \multirow{2}{*}{\multicolumn{4}{|c|}{$\begin{array}{l}\text { Pairwise Granger Causality Tests } \\
\text { Date: 09/05/16 Time: 00:55 }\end{array}$}} \\
\hline & & & \\
\hline \multicolumn{4}{|l|}{ Sample: 19892014} \\
\hline \multicolumn{4}{|l|}{ Lags: 1} \\
\hline Null Hypothesis: & Obs & F-Statistic & Prob. \\
\hline ROE does not Granger Cause ROA & 25 & 0.01006 & 0.9210 \\
\hline \multicolumn{2}{|l|}{ ROA does not Granger Cause ROE } & 2.74653 & 0.1117 \\
\hline LDR does not Granger Cause ROA & 25 & 5.80824 & $0.0248 *$ \\
\hline \multicolumn{2}{|l|}{ ROA does not Granger Cause LDR } & 1.24248 & 0.2770 \\
\hline NLTL does not Granger Cause ROA & 25 & 0.51752 & 0.4795 \\
\hline \multicolumn{2}{|l|}{ ROA does not Granger Cause NLTL } & 0.88709 & 0.3565 \\
\hline TLTA does not Granger Cause ROA & 25 & 0.13994 & 0.7119 \\
\hline \multicolumn{2}{|l|}{ ROA does not Granger Cause TLTA } & 0.80472 & 0.3794 \\
\hline LDR does not Granger Cause ROE & 25 & 3.06056 & 0.0942 \\
\hline \multicolumn{2}{|l|}{ ROE does not Granger Cause LDR } & 0.99283 & 0.3299 \\
\hline NLTL does not Granger Cause ROE & 25 & 7.19860 & $0.0136^{*}$ \\
\hline \multicolumn{2}{|l|}{ ROE does not Granger Cause NLTL } & 0.96492 & 0.3366 \\
\hline TLTA does not Granger Cause ROE & 25 & 0.32765 & 0.5729 \\
\hline \multicolumn{2}{|l|}{ ROE does not Granger Cause TLTA } & 1.73768 & 0.2010 \\
\hline NLTL does not Granger Cause LDR & 25 & 0.26479 & 0.6120 \\
\hline \multicolumn{2}{|l|}{ LDR does not Granger Cause NLTL } & 0.11808 & 0.7344 \\
\hline TLTA does not Granger Cause LDR & 25 & 0.29695 & 0.5913 \\
\hline \multicolumn{2}{|l|}{ LDR does not Granger Cause TLTA } & 0.61204 & 0.4424 \\
\hline TLTA does not Granger Cause NLTL & 25 & 3.50879 & 0.0744 \\
\hline \multicolumn{2}{|l|}{ NLTL does not Granger Cause TLTA } & 3.51556 & 0.0741 \\
\hline
\end{tabular}

Source: Author's compilation from Eviews

The Granger causality test results presented in Table 4.7 reveals the direction of causality between the various variables representing bank performance (ROA and ROE) and credit risk management variables. The results above indicate that there is a unidirectional granger causality relationship running from LDR to ROA and also from NLTL to ROE respectively.

This study shows that there is a significant relationship between bank performance and credit risk management. Loans and advances and non performing loans are major variables in determining asset quality of a bank. These risky items are important in determining the profitability of banks in Nigeria. Where a bank does not effectively manage its risk, its profit will dwindle. This means that the profit after tax has been responsive to the credit policy of Nigerian banks. Banks become more concerned because loans are usually among the riskiest of all assets and therefore may threatened their liquidity position and lead to distress. Better credit risk management results in better bank performance. Thus, it is of crucial importance for banks to practice prudent credit risk management to safeguard their assets and protect the investors' interests.

\section{Conclusion}

This work is an analysis of the impact of credit risk management on the performance of deposit money banks. In summary, the findings demonstrate succinctly, that the selected credit risk 
management indicators under study significantly affect the performance of deposit money banks in Nigeria. But the measure of relationship differs according to the different performance indicators. Therefore, the result of our econometric tests leads us to conclude that there is a significant relationship between the various credit risk management indicators employed in this study and the performance of deposit money banks in Nigeria.

\section{RECOMMENDATIONS}

The following strategies are recommended in other to improve banks performance and profitability in Nigeria. (1). Management need to be cautious in setting up a credit policy that will not negatively affect the operations of their banks in order to ensure judicious utilization of deposits and maximization of profit. (2) CBN for policy making purpose should regularly assess the lending attitudes of deposit money banks and effective cash management policies to avoid insolvency in the financial system. (3). Determining the credit worthiness of a customer whether individual or corporate organization must be carefully planned. A rush into the approval of loan without sourcing adequate and relevant information on the prospective borrowers must be avoided if the bank wishes to circumvent delays in the recovery of debt. (4). To increase credit volume, the interest rate policy must be considered within the frame of economic circumstances of the time for low interest rate does facilitate quick repayment and drastically minimize debt failure.

\section{REFERENCES}

[1] Ahmed, N. H., \& Ariff, M. (2007). Multi-country Study of Bank Credit Risk Determinants International Journal and Finance 5(1), pp.135-152

[2] Ahmed, A. S., Takeda, C, and Shawn, T. (1998). Bank loan loss provision: A Reexamination of Capital Management and Signaling Effects, Working Paper. Department of Accounting, Syracuse University, 1-37.

[3] Azizi, N. A., Ibrahim, I. I. \& Isa, M. B. (2009). The impact of Non-performing loans (NPL) towards profitability (ROA, ROE and NPM). Research report to the research management institute, India.

[4] Basel Committee on Banking Supervision (1982). "Management of Banks' International Lending", Country Risk Analysis and Country Exposure Measurement and Control. www.bis.org.

[5] Basel Committee on Banking Supervision (1999). "Principles for the Management of Credit Risk", CH-4002 Basel, Switzerland Bank for International Settlements.

[6] Basel Committee on Banking Supervision (2001). Risk Management Practices and Regulatory Capital: Cross- Sectional Comparisons. www.bis.org.

[7] Chen, K. and Pan, C. (2012). An empirical study of Credit Risk Efficiency of Banking Industry in Taiwan, Web Journal of Chinese Management Review, 15(1), 1-16.

[8] De Young, R. and Whalen, G. (1994). "Banking Industry Consolidation: Efficiency Issues", working paper No. 110. A conference of the Jerome Levy Economics Institute, office of the comptroller of the currency, Washington, DC.

[9] Felix, A. T. and Claudine, T. N. (2008). "Bank performance and credit risk management". Unpublished Masters Dissertation in Finance, University of Skovde.

[10] Kargi, H. S. (2011). Credit risk and the performance of Nigerian Banks, Ahmadu Bello University, Zaria.

[11] Kithinji, A. M. (2010). Credit risk management and profitability of commercial banks in Kenya, School of Business, University of Nairobi, Nairobi.

[12] Lindgren, H. (1987). Banks, investment company, banking firms, Stockholm Enskilda Bank (1924-1945), Institute for Research in Economic History, Stockholm School of Economics, Stockholm.

[13] Owojori, A. A. Akintoye, I. R. and Adidu, F. A. (2011). "The challenge of risk management in Nigerian banks in the post consolidation era", Journal of Accounting and Taxation Vol. 3(2). pp. 23-31. 
[14] Robert, D. and Gary, W. (1994) "Banking industry consolidation: Efficiency Issues", working paper No. 110 presented at the financial system in the decade ahead: A conference of the Jerome Levy Economics institute, April 14-16, 1994.

[15] Sanusi J. (2002) "Central Bank and the macroeconomic environment in Nigeria". Quarterly Review, Vol. 03, no. 3 December.

[16] Uchendu, G. A. (2005). Banking sector reforms and bank consolidation: The Malaysian experience, Bullion, 29(2).

Citation: Harcourt, Edwin E. "Credit Risk Management and Performance of Deposit Money Banks in Nigeria." International Journal of Managerial Studies and Research (IJMSR), vol 5, no. 8, 2017, pp. 47-56. doi:http://dx.doi.org/10.20431/2349-0349.0507006.

Copyright: $\odot 2017$ Authors. This is an open-access article distributed under the terms of the Creative Commons Attribution License, which permits unrestricted use, distribution, and reproduction in any medium, provided the original author and source are credited. 